\title{
PRO-KONTRA PEMULANGAN WARGA NEGARA INDONESIA EKS ISIS
}

\author{
Abdurrahman Hakim, Iffatin Nur \\ Pascasarjana IAIN Tulungagung \\ E-Mail: Cakman1996@Yahoo.com, Iffaeltinury@gmail.com
}

\begin{abstract}
This paper aims to analyze the policies of the government that decides do not repatriate former Indonesian citizens of sympathizers ISIS in Iraq and Syria. The theory that used to analyze the case is theory of maqashid al-shari'ah Jasser Auda. Theories of maqashid alshari'ah Jasser Auda considered very relevant in this case because of the ideas that were brought consider universal human rights enforcement. This is different from the previous theory of maqashid al-shari'ah which only had an individual function protection and persevation. Theory of maqashid al-shari'ah Jasser Auda is reconstruction of the concept of previous scholars with the aim of revitalizing the values of maqoshid value with contemporary problems, especially in terms of enforcement of the human rights (hifżu al-nafs). In addition, the writer consider that the idea of human rights has a correlation with article 28J paragraphs 1 and 2 of the 1945 Constitution which form the basis of limitations on fulfillment of individual rights. Next, not all of ISIS sympathizers are the perpetrators of terrorism, therefore the writer offer a deradicalization effort for children and sympathizers' wives before returning to community life. As victims, they have the right education on the good ideology (hifzu al-aql) and still carry out the function of heredity (hif?̦u al-nasl).
\end{abstract}

Key words:

maqashid al-shari'ah; deradicalization; hifẓu al-nafs; hifł̣u al-aq; hifẓu al-nasl.

\section{Abstrak}

Tulisan ini bertujuan untuk menganalisis kebijakan pemerintah yang memutuskan untuk tidak memulangkan kembali warga negara Indonesia mantan simpatisan ISIS di Iraq dan Suriah. Teori yang dipakai untuk analisis kasus tersebut adalah teori maqashid alsyari'ah Jasser Auda. Teori maqashid al-syari'ah Jasser Auda dinilai sangat relevan dalam kasus ini karena gagasan yang dibawa mempertimbangkan penegakan hak azasi secara universal. Hal ini 
berbeda dengan teori maqashid al-syari'ah sebelumnya yang hanya memiliki fungsi individual protection dan persevation. Teori maqāșid al-syarïah Jasser Auda adalah rekontruksi konsep ulama-ulama sebelumnya dengan tujuan merelevansikan nilai-nilai maqoshid dengan masalah-masalah kontemporer, terutama dalam hal penegakan hak hidup manusia (hifz al-nafs). Selain itu, penulis menganggap bahwa gagasan hak asasi manusia tersebut memiliki korelasi dengan Pasal 28J ayat 1 dan 2 Undang-undang dasar 1945 yang menjadi dasar pembatasan atas pemenuhan hak individu. Berikutnya, tidak semua dari simpatisan ISIS adalah pelaku terorisme, oleh sebab itu penulis menawarkan upaya deradikalisasi bagi anakanak dan istri simpatisan tersebut sebelum kembali hidup bermasyarakat. Sebagai korban, mereka memiliki hak memperoleh pendidikan atas ideologi yang baik (hifz় al-aql) dan tetap menjalankan fungsi keturunanya (hifz al-nasl).

Kata kunci:

Maqashid al-syari'ah; deradikalisasi; hifz al-nafs; hifẓ al-aql; hifz় alnasl.

\section{A. PENDAHULUAN}

Pasca dinyatakan kalah pada tahun 2019, muncul permasalahan baru yaitu bagaimana nasib eks ISIS yang masih tersisa. Pasalnya, tidak semua simpatisan ISIS berasal dari Iraq dan Suriah, banyak pula dari mereka yang berasal dari negaranegara berpenduduk muslim, salah satunya dari Indonesia. Hingga bulan Pebruari 2020, pemerintah mencatat bahwa ada sekitar 687 orang simpatisan yang dinyatakan sebagai WNI. Rumitnya lagi, bahwa tidak semua dari 687 orang itu adalah kepala keluarga, ada juga anak-anak dan istri yang terpaksa ikut kepala keluarganya menjadi simpatisan. ${ }^{1}$

Ada beberapa kelompok yang menerima pemulangan mereka, dan ada juga yang menolak dengan keras dengan alasan akan menjadi bibit terorisme baru di Indonesia. Penolakan yang paling keras berasal dari keluarga korban berbagai kasus terorisme yang perah terjadi di Indonesia. Dalam lima tahun terakhir saja (2015-2020) tercatat ada lima kasus yang dikonfirmasi sebagai ulah ISIS, bom Tahmrin, rencana serangan pos polisi di Tanggerang, jaringan Majalengka, bom Mapolresta Surakarta dan Teror 17 Agustus di Solo pada 2015.²

${ }^{1}$ Andika Prastia, Tok! Pemerintah Tak Akan Pulangkan WNI eks ISIS, news.detik.com/ berita/d-4894943/tok-pemerintah-tak-akan-pulangkan-wni-eks-isis diakses pada 11 April 2020.

2 Yus Ariyanto, 5 jejak ISIS di Indonesia, https://www.liputan6.com/news/read diakses pada 21 April 2020. 
ISIS atau Islamic State of Iraq and Suria merupakan teroris internasional yang dipimpin Abu Bakar al-Baghdadi. Organisasi tersebut oleh dunia barat dikenal dengan istilah organisasi "Islam garis keras". Stigma negatif barat terhadap Islam salah satunya akibat berbagai kasus terorisme yang terjadi di berbagai negara Eropa. Padahal jika dikaji secara mendalam mengenai ideologi mereka, maka sangat jauh dari ideologi Islam yang sebenarnya.

Pemulangan eks ISIS terhalang oleh kebijakan deradikalisasi yang menjadi program pemerintah dalam menekan ideologi radikal di Indonesia. Deradikalisasi bertujuan untuk mengecegah paham reaktif di masyarakat akibat ketidak adilan dan propaganda ketidak adilan oleh oknum-oknum tertentu. Sehingga, jika eks ISIS tetap dipuangkan, maka untuk mensukseskan deradikalisasi akan menemui kegagalan. Hal ini karena objek deradikalisasi adalah pemuda-pemuda yang masih memiliki pemahaman ideologi yang sesuai dengan Pancasila.

Keputusan terakhir pemerintah untuk tidak memulangkan WNI tersebut menjadi sorotan berbagai kalangan. Salah satunya adalah Komisi Nasional Hak Asasi Manusia (KOMNAS HAM). Ketua Komnas HAM, Ahmad Taufan menyarankan pemrintah agar tidak mengaggap sama semua WNI yang menjadi simpatisan ISIS. Harus ada pendataan yang melibatkan BNPT untuk mengtahui secara jelas profil mereka. Ia juga menyarankan agar pemerintah menerapkan Pasal 26B yaitu memberi hukuman penjara antara 7-12 tahun. ${ }^{3}$

Penelitian ini penting karena ada inkorelasi antara pemerintah dengan Komnas HAM. Satu sisi, Komnas HAM berharap mereka hanya mendapat hukuman penjara, di sisi lain pemerintah sedang gencar melakukan program deradikalisasi untuk menekan jumlah teorism di Indonesia. Oleh sebab itu, penulis mencoba membandingkan dua pendapat tersebut melalui konsep mașlahah.

\section{B. KAJIAN TEORI}

\section{Radikal, Radikalisme dan Deradikalisasi}

Oleh sebagian kalangan, radikal, radikalisme dan deradikalisasi sebagai suatu rangkaian kata yang memiliki makna sama. Padahal secara terminologi, kata-kata tersebut memiliki arti dan fungsi yang berbeda. Radikal adalah pemahaman seseorang yang berfikir secara mendalam mengenai suatu hal, bisa dalam aspek sosial, ekonomi, politik bahkan hukum. Menurut KH Hasyim Muzadi, mantan ketua PBNU, pemikiran seperti boleh-boleh saja dan tidak ada larangan dalam Islam. ${ }^{4}$

${ }^{3}$ Rahel Narda Chatrine, Soal WNI eks ISIS, Komnas HAM sarankan Pemerintah Lakukan Profilling, https://news.detik.com/berita/d-4892152/soal-wni-eks-isis-komnas-ham, dikses pada 14 April 2020.

${ }^{4} \mathrm{Abu}$ Rakhmad, "Radikalisme Islam dan Upaya Deradikalisasi Paham Radikal". Jurnal Walisongo, 1.12 (2012), h.82 
Ideologi radikal adalah ideologi seseorang yang tidak muncul secara kebetulan, melainkan ada beberapa faktor yang mempengaruhi. Yusuf Qordawi berpendapat bahwa idologi radikal adalah pola pikir seseorang yang berubah dari ideologi asal karena lemahnya pengetahuan tentang hakikat agama dan sejarah mengenai teks Al-quran. ${ }^{5}$ Hakikat al-Quran sebagai dasar Hukum Islam memiliki pengaruh besar pada pola pikir umat Islam. Jika hanya dipahami secara tekstual, akan banyak penafsiran yang melenceng dari sebab ayat tersebut diturunkan dan dalam konteks apa ayat itu difungsikan. Ideologi radikal memiliki makna yang sama dengan radikalisme dan sudah mencakup beberapa kelompok masyarakat. Radikalisme adalah radikal yang sudah menjadi paham dan isme di masyarakat dan tumbuh menjadi kekuatan sehingga menimbukan teror. ${ }^{6}$ Kekuatan ini nyata, meluas dan jika tidak segera antisipasi oleh pemerintah, akan menjadi wadah bagi korban kebijakan khususnya kaum marginal.

Deradikalisasi memiliki arti berbeda dengan radikal dan radikalisme, meski berasa dari suku kata yang sama yaitu radikal. Deradikalisasi berasal dari bahasa Inggris "deradicalization" yaitu usaha untuk mengajari, memberi pemahaman dan langkah untuk mengembalikan sikap seseorang menjadi pluralis, toleran, lunak dan moderat. ${ }^{7}$ Objek deradikalisasi adalahm mengembalikan paham radikal dan radikalisme di masyarakat hingga tidak mennyebabkan konflik. Paham ini perlu untuk dideteksi sejak dini oleh pemerintah agar tidak menyabar secara luas di masyarakat.

\section{Hak Asasi Manusia}

Kebijakan pemerintah dalam ranah hukum dan politik sering kali berbenturan dengan upaya penegakan hak asasi manusia. Banyak kebijakan permerintah yang dikritik oleh berbagai pihak salah satunya mengenai sikap larangan kembali ke Indonesia bagi WNI eks ISIS. Pada dasarnya, definisi hak asasi manusia yang dijadikan dasar untuk mengkritik kebijakan pemerintah tidak sesederhana itu.

Hak asasi manusia atau human right didefinisikan sebagai anugrah yang diberikan kepada manusia sebagai konsekuensi sebagai makhluk ciptaan Tuhan yang maha esa. ${ }^{8}$ Dalam kaitannya dengan negara, negara sebagai wadah untuk menghormati, menjamin dan memenuhi fitrah manusia tersebut. Pemenuhan hak asasi manusia oleh negara moderen dijamin dengan adanya konstitusi tertulis hasil musyawarah dan mufakat pemerintah.

\footnotetext{
${ }^{5}$ Yusuf Qardhawi, Pemikiran Yusuf Qhardawi dalam Timbangan, terj. M. Abdul Ghoffar, (Bogor: Pustaka Imam Syafi'i, 2003), h.88

${ }^{6}$ Abu Rakhmad, Radikalisme Islam dan Upaya, h.83

${ }^{7}$ M. Marwan dan Jimmy. P, Kamus Hukum, (Yogyakarta: Pustaka Pelajar, 2009), h.519

8 Osgar S Matompo. "Pembatasan Terhadap Hak Asasi Manusia Dalam Prespektif Keadaan Darurat." Media Hukum 21.1 (2014): 58
} 
Undang-undang dasar 1945 awalnya sama sekali tidak memiliki pasal yang mengatur perlindungan HAM. Hal ini karena rancangan UUD 1945 yang dibuat oleh BPUPKI masih menggunakan asas kekeluargaan. Asas kekeluargaan adalah asas yang menentang paham individualisme dan liberalisme. ${ }^{9}$ Sehingga, pasal yang melindungi kepentingan individu tidak masuk dalam rancangan tersebut. Hak asasi manusia merupakan hak yang melekat secara kuat sebagai hakikatnya sebagai manusia. ${ }^{10}$ Dalam hal ini, hak bukanlah pemberian negara pada individu, sehingga negara hanya bertugas untuk memenuhi apa yang sudah menjadi haknya, melindungi dari intimidasi pihak lain dan menghormati untuk tidak sekali-kali mencabut pemenuhan hak tersebut tanpa suatu alasan. Meski sejarah mencatat bahwa hak asasi manusia adalah respon perilaku berbagai kelompok yang membahayakan hak, namun fitrahnya hak asasi manusia sudah ada sejak manusia itu dilahirkan.

Sebagai upaya dalam menjalin interaksi dengan sesama manusia, hak asasi manusia dijadikan asas yang dibuat dari beberapa nilai yang kemudian menjadi kaidah-kaidah untuk mengatur interaksi tersebut. Dalam hal ini, kaidah-kaidah yang berlaku menjadi batasan perilaku manusia agar tidak melanggar hak orang lain. ${ }^{11}$ Sedangkan norma adalah tolak ukur mengenai kepantasan perilaku yang pada dasarnya akan menjadi penilaian tersendiri mengenai kualitas kepantasan mengenai tingkah laku apa saja yang bisa dilakukan dalam berinteraksi.

Begitupula hubungan idividu dengan negaranya, hak asasi manusia adalah landasan berperilaku agar negara tetap menghormati hak individu setiap bangsa dan juga sebaliknya, setiap individu wajib mematuhi aturan yang sudah ditetapkan negara untuk menjaga stabilitas hak antar individu, antar kelompok dan individu dengan kelompok. Jimly Ashiddiqie bependapat bahwa gagasan HAM pasca revormasi sangat jelas diatur dalam UUD 1945. Di Indonesia, norma hukum tentang HAM terbagi menjadi berapa bagian yaitu: a, hak-hak sipil; $b$, hak-hak politik, sosial dan budaya; c, hak-hak khusus dan pembangunan; d, hak-hak untuk mendapat pertanggung jawaban dari negara. Hak-hak tersebut merukapan hak-hak yang wajib dipenuhi, dihormati dan dijaga oleh negara bagi seluruh warga negara Indonsia. ${ }^{12}$

Adanya HAM adalah respon terhadap banyaknya kasus pelanggaran yang menimpa seseorang sehingga apa yang semestinya mereka dapat sebagai manusia

\footnotetext{
${ }^{9}$ Jimly Ashiddiqie, Pengantar Hukum Tatanegara II. (Jakarta: Sekretaris jenderal Kepaniteraan Mahkamah Konstitusi RI, 2016), hal.96

${ }^{10}$ Majda El Muhtaj, Hukum dan Hak Asasi Manusia dalam Konstitusi Indonesia, (Jakarta: Kencana, 2015), h. 6

${ }^{11}$ Majda El Muhtaj, Hukum dan Hak Asasi Manusia dalam Konstitusi Indonesia, h.43-44

12 Jimly Ashiddiqie, Pengantar Hukum Tatanegara, h.105-109
} 
itu hilang. Mengaca dari sejarah pelanggaran HAM, ada beberapa kategori tindakan yang termasuk pelanggaran HAM. ${ }^{13}$

Pertama, pembunuhan massal (genocide) adalah gerakan kelompok tertentu dengan segaja melakukan pembunuhan pada kolompok yang lain di suatu daerah. Genosida dilakukan karena berbagai alasan, diantaranya kondisi sosial, politik dan ekonomi. ${ }^{14}$ Dalam sejarah, genosida sering dilakukan oleh pemerintah pada suatu kelompok menggunakan kekuatan militernya. Contoh genosida yang pernah terjadi di dunia intrnasional termasuk Indonesia adalah G30S/PKI, tragedi Patani dan tragedi muslim Myanmar.

Kedua, pembunuhan dengan sewenang-wenang atau di luar putusan pengadilan (arbitrary/extra yudicial killing) merupakan salah satu bentuk pelanggaran HAM di negara hukum. Salah satu ciri negara hukum adalah dakwaan kasus pidana yang menjatuhkan hukuman mati pada seseorang harus diputuskan di pengadilan. Maksudnya, tindakan yang menyebabkan hilangnya nyawa seseorang dapat dibenarkan asal sesuai dengan aturan yang berlaku di negara tersebut.

Ketiga, penyiksaan adalah perlakuan seseorang yang melebihi batas wajar sehingga menghilangkan hak fundamental dari seseorang. ${ }^{15}$ Berbagai kasus penyiksaan yang ada di dunia mayoritas dilatar belakangi adanya demonstrasi yang dianggap membahayakan kekuasaan pemerintah. Menangapi permasalahan tersebut, banyak negara hukum yang akhirnya membuat aturan tentang perlindungan bagi demonstran. ${ }^{16}$

Keempat, penghilangan atau penculikan orang secara paksa adalah salah satu bentuk pelanggaran HAM yang sering terjadi. Penculikan masuk dalam kategori pelanggaran HAM kerena secara paksa mengambil hak kebebasan seseorang. Kasus penculikan rentan terjadi pada anak-anak dengan tujuan ekspoitasi. Umumya eksploitasi bertujuan untuk pelacuran, penyiksaan, perbudakan, kerja atau perlayanan paksan dan sejenisnya. ${ }^{17}$

Kelima, perbudakan atau mamaksa seseorang untuk bekerja tanpa adanya balasan berupa gaji dan balas jasa merupakan salah satu bentuk pelanggaran HAM. (2016), h.82

${ }^{13}$ Eko Hidayat. "Perlindungan hak asasi manusia dalam negara hukum indonesia". ASAS 8.2

14 Wahyu Wirawan. "PERAN MILITER DALAM GERAKAN MASSA DAN PEMBUNUHAN MASSAL DI JAWA-BALI." Jurnal Historia, 23.2 (2013), h.4-6

${ }^{15}$ Amira Rahma Sabla. "Kajian Freedom of Speech and Expression dalam Perlindungan Hukum terhadap Demonstran di Indonesia." Lex Scientia Law Review 1.01 (2017), h.90

${ }^{16}$ Amira Rahma Sabla. "Kajian Freedom of Speech and Expression dalam Perlindungan Hukum terhadap Demonstran di Indonesia." Lex Scientia Law Review 1.01 (2017), h.88

${ }^{17}$ Edwin Tumundo, ."PENYIDIKAN TINDAK PIDANA PERDAGANGAN ORANG PADA TINGKAT KEPOLISIAN DALAM PERSPEKTIF HAK ASASI MANUSIA." LEX ET SOCIETATIS 6.4 (2018), h.87 
Salah satu poin utama disepakatinya "The Universal Declaration of Human Rights" adalah penghapusan perbudakan akibat penjajahan. Tidak hanya itu, segala bentuk perlakuan yang semena-mena atas kebebasan seseorang dan dinilai mencederai hakhak yang semestinya didapat sebagai orang merdeka juga masuk dalam kategori perbudakan. ${ }^{18}$

Keenam, diskriminasi secara sistematis adalah upaya membatasi hak seseorang yang sudah dijamin oleh konstitusi. Diskriminasi sering dialami kelompok masyarakat yang memiliki strata sosial yang rendah dan dianggap kaum marginal. ${ }^{19}$

\section{Konsep Maṣlahạ}

Secara etimologi kata mașlaḥah berasal dari bahasa arab mașlahạ merupakan masdar dari fi'il madzi aslahah (membuat, menjadikan dan membentuk kebaikan). Kata aslaah dalam shorfiyah merupakan turunan kalimat shalaha yang artinya baik. Sehingga kata maṣlaḥạ juga bisa diartikan baik atau suatu keadaan yang jauh dari keburukan. ${ }^{20}$ Secara terminologi, mașlahah adalah keadaan yang bisa diukur secara material dan non-material dan mampu meningkatkan harkat dan martabat manusia sebagai makhluk yang paling mulia. ${ }^{21}$ Imam Ghazali mendefinisikan maslahah sebagai usaha untuk menjaga dan memelihara tujuan syariat, atau yang sering disebut degan maquạsid al-syarī'ah. Dalam beberapa kajian Islam, maqāṣid al-syarī'ah dikenal denga lima tujuan hukum Islam diberlakukan, yaitu: hifz al-dīn (menjaga agama), hifz al-'aql (menjaga akal), hifz al nafs (menjaga hidup), hifz al-nasl (menjaga keturunan) dan hifzh al mal (menjaga harta). ${ }^{22}$

Berbeda dengan pendapat Ghazali, Imam ash-Syatibi mendefinisikan Maṣlaḥah sebagai semua hal yang dibutuhkan oleh manusia baik kebutuhan jasmani maupun kebutuhan rohani. Hal ini agar manusia merasakan keyamanan dan kedamaian dalam menjalankan kehidupan di dunia dan kehidupan di akhirat. ${ }^{23}$

${ }^{18}$ Rifqi Muhammad Fatkhi and Reva Hudan Lisalam. "Membumikan HAM Mengikis Perbudakan (Kajian Mawḍ̂̀'î Terhadap Ḥadîts-ḥadîts Perbudakan)." Refleksi 17.2 (2018), h.152

${ }^{19}$ Merryany B Bawole. "Kajian Hak Asasi Manusia terhadap Perlakuan Diskriminasi Kepada Pekerja Seks Komersial." Jurnal Hukum UNSRAT 21.3 (2013), h.12-13

${ }^{20}$ Ahmad bin Faris bin Zakariya, Mu'jam Maqoyiz al-Lughah. (Beirut: Dar al-Fikr, 1979), h.303

21 Pusat Pengkajian dan Pengembangan Ekonomi Islam, Ekonomi Islam,(Jakarta: Radja Grafindo Persada, 2015), h.5

${ }^{22}$ Enden Haitami. "Perkembangan Teori Mashlahah 'Izzu Al-Dîn bin 'Abd Al-Salâm dalam Sejarah Pemikiran Hukum Islam”. Asy Syari’ah. 17.1 (2015), h.31

${ }^{23}$ Enden Haitami. "Perkembangan Teori Mashlahah 'Izzu Al-Dîn bin 'Abd Al-Salâm dalam Sejarah Pemikiran Hukum Islam”. Asy Syari'ah. 17.1 (2015), h.32

24 Pusat Pengkajian dan Pengembangan Ekonomi Islam, Ekonomi Islam, h.5 
Kemaslahatan merupakan tujuan utama dari kaidah-kaidah fiqh yang ada. Artinya, semua kaidah fiqh memiliki tujuan untuk membentuk suatu keadaan, keputusan dan klausul hukum yang memberi kemaslahatan bagi seluruh umat manusia. Kaidah-kaidah hukum yang dirumuskan dinilai bermanfaat dan sesuai dengan ajaran Islam jika outputnya berupa kemaslahatan.

Jika dilihat dari sejarah berkembangnya kaidah-kaidah fiqh, maslahah memiliki dua fungsi. Pertama, maslahah adalah tujuan hukum Islam dan kedua, maslahah adalah sumber hukum Islam yang berdiri sendiri. Kedua fungsi tersebut memiliki kaitan, yaitu semua sumber hukum Islam baik yang disepakati atau tidak memiliki tujuan mașlahah. Begitupula dengan maslahah sebagai sumber hukum tentunya sebagai landasan dalam mencari kemaslahatan itu sendiri.

Kajian maslahah merupakan kajian untuk memilih dasar hukum yang paling tepat dari berbagai penafsiran atas nash. Namun, antara satu nash dengan yang lain, antara satu penafsiran dengan penafsiran lain terkadang memiliki pertentangan. Dalam masalah inilah, klausul hukum ditentukan dari nash dengan dengan tingkat kemaslahatan yang lebih tinggi. Tidak hanya hukum terhadap kasus yang sudah ditentukan oleh nash, mașlahah juga memiliki kiprah yang sangat luas atas kasus yang tidak ada dasar hukumnya secara tekstual. ${ }^{25}$ Dalam teori ushul fiqh, mașlahah bisa dibagi menjadi tiga bagian berdasarkan ada dan tidaknya dalin nash pendukung suatu kemaslahatan: Mașlaḥah al-Mu'tabar yaitu, Maṣlahah al-Mu'tabar adalah kemaslahatan yang nashnya jelas dalam al-Quran dan al-Hadist. Sehingga para ulama sepakat bahwa penggunaan maslahah al-Mu'tabar dianggap sebagai dasar syariat yang otentik. Manifestasi dari maslahah ini adalah penggunaan qiyas. Maṣlaḥah al-Mulgah yaitu; Maṣlaḥah al-Mulgah adalah kemaslahatan yang ditolak oleh jumhur ulama. Mașlahah al-Mulgah dinilai bertentangan dengan syariat yang sudah dijelaskan dalam al-Quran dan al-Hadist. Meski mengandung unsur mașlahah̆ hal itu tetap tidak bisa diterima lantaran pemikiran demikian sudah menyalahi aturan tertinggi dalam Islam dan Mașlaḥặ al-Mursalah yaitu; Maṣlaḥaḥ al-Mursalah tidak diakui oleh syariat karena tidak berdasarkan pada nash. Namun, jumhur ulama tidak menolak ketentuan yang bersumber dari mașlahah tersebut karena memiliki nilai kebenaran yang universal dan secara substantif sama klausul hukumnya dengan kaidah-kaidah hukum.

\section{PEMBAHASAN}

\section{Larangan Pulang WNI Eks ISIS dalam perspektif HAM}

Larangan pemerintah untuk memulangkan WNI eks ISIS sampai saat ini masih menuai kritikan terutama dari komnas HAM dan Komnas Pelindungan Anak. Karena tidak semua dari mereka adalah pelaku teror, ada juga dari golongan istri

${ }^{25}$ Pusat Pengkajian dan Pengembangan Ekonomi Islam, Ekonomi Islam h.155 
dan anak yang dipaksa untuk mengikuti kepala keluarganya menjadi simpatisan ISIS. Deklarasi Universal Hak Asasi Manusia menybutkan bahwa "Setiap orang berhak meninggalkan suatu negeri, termasuk negerinya sendiri, dan berhak kembali ke negerinya". ${ }^{26}$

Hak tersebut berlaku untuk warga negara-negara yang merativikasi DUHAM, diantaranya Indonesia. Dalam konstitusi Indonesia sendiri disebutkan bahwa warga negara adalah "(1) Yang menjadi warga negara ialah orang-orang bangsa Indonesia asli dan orang-orang bangsa lain yang disahkan dengan undang-undang sebagai warga negara. (2) Penduduk ialah warga negara Indonesia dan orang asing yang bertempat tinggal di Indonesia. (3) Hal-hal mengenai warga negara dan penduduk diatur dengan undangundang.". 27

Ratifikasi terhadap pasal-pasal yang ada dalam DUHAM sama halnya Indonesia juga memberlakukan pasal-pasal tersebut di wilayah Indonesia. Namun dalam praktinya, tidak semua pasal yang ada dalam DUHAM diberlakukan begitu saja. Hal ini seseuai dengan ketentuan yang ada dalam Pasal 28J "(1) Setiap orang wajib menghormati hak asasi manusia orang lain dalam tertib kehidupan bermasyarakat, berbangsa, dan bernegara. (2) Dalam menjalankan hak dan kebebasannya, setiap orang wajib tunduk kepada pembatasan yang ditetapkan dengan undang-undang dengan maksud sematamata untuk menjamin pengakuan serta penghormatan atas hak dan kebebasan orang lain dan untuk memenuhi tuntutan yang adil sesuai dengan pertimbangan moral, nilai-nilai agama, keamanan, dan ketertiban umum dalam suatu masyarakat demokratis."28

Jimly Ashiddiqie menyebutkan bahwa Pasal 28J adalah penghormatan setiap individu terhadap hak orang lain. Ada empat poin penting yang menjadi tanggung jawab negara dan kewajiban asasi sesorang terhadap negara dan orang lain: ${ }^{29}$ Setiap orang memiliki kewajiban yang sama untuk menghormati dan saling menjaga pemenuhan hak demi terciptanya kehidupan yang tertib dalam berbangsa dan bernegara. Dalam rangka memenuhi haknya masing-masing, setiap warga negara dibatasi oleh aturan yang berlaku demi menciptakan keadilan berdasarkan nilai-nilai moralitas, agama, kesusilaan, keamanan dan ketertiban masyarakat umum. Negara memiliki kewajiban untuk memajukan, melindungi, menegakkan dan memenuhi hak setiap warga negara.

Menyikapi penolakan pemerintah untuk memulangkan WNI eks ISIS, ketentuan di atas dapat diterapkan untuk menjadi pertimbangan. Berbeda dengan klausul hukum yang ada dalam DUHAM, UUD 1945 khususnya Pasal 28J memiliki

\footnotetext{
${ }^{26}$ Ketentuan Pasal 13 ayat 2 DUHAM.

27 Ketentuan Pasal 26 ayat 1,2 dan 3 UUD 1945.

${ }^{28}$ Ketentuan pasal 28J ayat 1 dan 2 UUD 1945

${ }^{29}$ Jimly Ashiddiqie, Pengantar Hukum Tatanegara, h.108
} 
otoritas tersendiri dalam mengatur ketertiban di dalam negeri mengenai permasalahan HAM

\section{Upaya Deradikalisasi}

Jika seandinya pemerintah menerima pemulanan WNI eks ISIS ke Indonesia, maka program deradikalisasi bisa menjadi upaya terbaik untuk mengembalikan ideologi mereka sesuai dengan ideologi pancasila. Namun, permasalahannya ialah ideologi bukanlah hal yang mudah diubah, karena sudah menjadi isme dan mengakar dalam pola pikir seseorang.

Penanganan radikalisme di Indonesia adalah tugas dari Badan Nasional Penanggulangan Trorisme (BNPT). Namun, mengingat radikalisme adalah suatu paham dan pola pikir, maka upaya penanganan radikalisme lebih tepat dilakukan melalui program pendidikan deradikalisasi. Pendidikan deradikalisasi bertujuan untuk membentuk pola pikir seseorang yang bisa menerima keragaman di Indonesia. Dalam hal ini, pendidikan menjadi kunci utama untuk menyadarkan adanya keberagaman berbasis inklusivisme, multikulturalisme dan pluralisme di Indonesia. Tujuannya agar setiap individu memiliki wawasan agama yang toleran dan memahami konsep kebenaran yang relaltif. ${ }^{30}$

Ideologi radikal erat kaitannya dengan dimensi agama, maka pendidikan yang baik adalah pendidikan dengan latar belakang agama yang menerima kemajemukan di Indonesia yaitu pendidikan pesantren. Menurut Yusuf Qhardawi, ada beberapa cara melalui pendidikan untuk mengatasi permasalahan radikalisme. Pertama, melalui pembelajaran agama dengan metode-metode yang telah dibuat oleh ulama untuk membentuk pemahaman mendalam tentang esensi agama guna menjadi muslim yang bijaksana dalam menyikapi perbedaan. Kedua, tidak memahami Islam secara instan, parsial dan reduktif. ${ }^{31}$

Pendidikan pesantren di Indonesia mengacu pada metode pengajaran yang dilakukan oleh imam madzhab. Imam Syafi'i dalam mendidik muridnya sering mengatakan "Pendapatku benar tapi mungkin salah, pendapat orang lain salah tapi bisa saja itu yang benar". Kata-kata tersebut adalah bentuk kepedulian Imam Syafi'i agar muridnya terhindar dari sifat absolutisme dan dogmatisme yang menganggap dirinya selalu benar. ${ }^{32}$

30 Andik Wahyun Muqoyyidin. "Membangun kesadaran inklusifmultikultural untuk deradikalisasi pendidikan Islam." Jurnal Pendidikan Islam 2.1 (2013), h.150

31 Yusuf Qardhawi. Masyarakat Berbasis IslamI, terj. Abdus Salam Masykur. (Solo: PT Era Adicitra Intermedia, 2013): h.132

32 Irwan Masduqi. "Deradikalisasi Pendidikan Islam Berbasis Khazanah Pesantren." Jurnal Pendidikan Islam 2.1 (2013), h.10 
Metode pengajaran yang diterapkan pesantren memiliki kekhasan yang tidak dimiliki oleh lembaga pendidikan lainnya. Meski zaman sudah dianggap modern dan sistem pendidikan dituntut untuk berubah dengan memanfaatkan canggihnya teknologi, pendidikan di pesantren tetap menggunakan metode pembelajaran yang dikenal dengan istilah sorongan wtonnan dan metode klasikal. Ciri khas kultur pendidikan pesantren antara lain; a) mendidik para santri untuk menghormati guru, kyai dan orang lain, 2) membangun sifat kasih sayang antara senior dan junionya, 3) hukuman bagi santri biasanya bersifat non-fisik, 4) memakai pakaian Islami setiap harinya, 5) berafiliasi kultur Nahdlatul Ulama, 6. Sistem penerimaan santri tanpa seleksi, 6) biaya pendidikan yang murah. ${ }^{33}$

Untuk mencegah pemahaman yang radikal tentang Islam, santri di Pondok pesantren dibekali dengan pengetahuan-pengetahuan agama yang mumpuni, diantaranya; a) memahami keilmuan Islam yang murni dari kitab-kitab kuning dan literatur klasik, b) memahami ilmu gramatika seperti nahwu, mantiq, balaghah dan sharaf, c) memiliki kemampuan membaca kitab kuning dan literatur klasik dengan arti permakna dan terjemahan bebas. ${ }^{34}$

\section{Pertimbangan Mașlahah}

a). Pemenuhan Hak Asasi Manusia

Untuk mengukur mașlahah yang timbul karena penolakan atas kembalinya WNI eks ISIS di Indonesia, maka konsep Maqāșid yang relevan adalah konsep Maqāșid Jasser Auda. Upaya rekontruksi tujuan hukum Islam yang dilakukan Jasser Auda merupakan hasil pemikirannya yang menganggap bahwa konsep Maqāṣid alsyariah klasik yang hanya bersifat individual (protection) dan pelestarian (prsevation). ${ }^{35}$ Hasilnya, konsep itu hanya berlaku berdasarkan subjektifitas dan mengabaikan kemaslahatan yang bisa dirasakan secara universal. Untuk menciptakan kemaslahatan yang bersifat kemanusiaan dan peduli pada hak asasi manusia orang lain, Jasser Auda mengklasifikasi Maqāṣid al-syariah kontempor menjadi tiga bagian: ${ }^{36}$

Maqāṣid general yaitu Maqāșid yang memuat seluruh tujuan hukum Islam termasuk juga di dalamnya dzaruriyat dan hajiyyat dan ditambah tujuan Maqāṣid yang baru yaitu pemenuhan fasiltas dan keadilan; Maqāșid partial yaitu Maqāṣid yang bertujuan untuk menemukan suatu kebenaran, keadilan, persaksian dan mengurangi

33 Nur Kholis. "Pondok pesantren salaf sebagai model pendidikan deradikalisasi terorisme." Akademika: Jurnal Pemikiran Islam 22.1 (2017), h. 161

34 Nur Kholis. "Pondok pesantren salaf sebagai model pendidikan deradikalisasi terorisme." Akademika: Jurnal Pemikiran Islam 22.1 (2017), h. 163

35 Siti Mutholingah dan Muh. Rodhi Zamzami, Relevansi Pemikiran Maqashid Al-Syari'ah Jasser Auda Terhadap sistem Pendidikan Islam Multidisipliner, Ta'limuna. 7.2 (2018), h.106

36 Siti Mutholingah dan Muh. Rodhi Zamzami, Relevansi Pemikiran Maqashid Al-Syari'ah Jasser Auda Terhadap sistem Pendidikan Islam Multidisipliner, Ta'limuna. 7.2 (2018), h.107 
kesulitan; Maqāṣid spesific yaitu Maqāṣid yang memiliki tujuan tertentu dalam hukum Islam seperti kesejahteraan anak dan mencegah kriminal.

Dalam menimbang maṣlaḥhh, menurut Abu Zahra, maṣlaḥah yang paling utama adalah maṣlaḥah bagi manusia. Maṣlaḥah tersebut secara umum menjadi tujuan syariat yang paling utama. Menurut jumhur fuqaha', mașlahah merupakan dalil hukum Islam. Sehingga, selama tidak diputus berdasarkan hawa nafsu dan tidak bertentangan dengan nash, maka bisa dijadikan acuan hukum. ${ }^{37}$

Hifz al-nafs sebagai upaya penghormatan terhada hak asasi manusia yang bersifat universal. Menjaga hidup sama halnya dengan melakukan kewajiban yang diamanahkan oleh Allah Swt. Menjaga hidup tidak bisa diartikan secara subjektif, namun juga harus objektif. Jika perintah Allah agar manusia menjaga nyawanya, maka Ia juga memiliki kewajiban untuk menjaga nyawa orang lain. Salah satu firman Allah dalam Qs. al-Isra'/17:33.

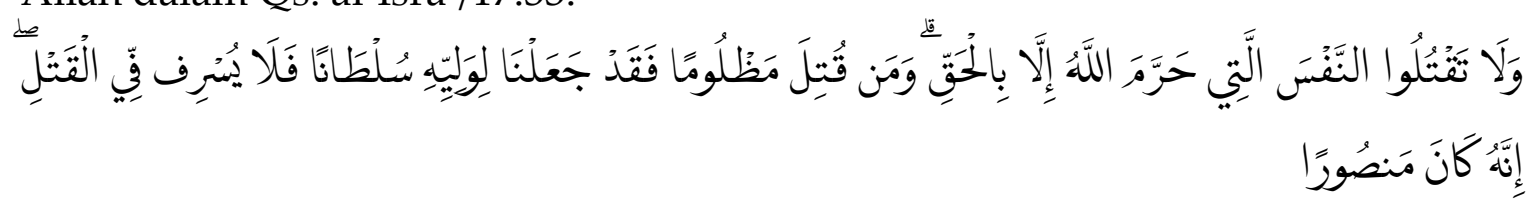

Terjemahnya :

"Dan janganlah kamu membunuh jiwa yang diharamkan Allah (membunuhnya), melainkan dengan suatu (alasan) yang benar. Dan barangsiapa dibunuh secara zalim, maka sesungguhnya Kami telah memberi kekuasaan kepada ahli warisnya, tetapi janganlah ahli waris itu melampaui batas dalam membunuh. Sesungguhnya ia adalah orang yang mendapat pertolongan." ${ }^{38}$

Firman Allah tersebut adalah larangan bagi umat Islam untuk membunuh jiwa yang berhak untuk hidup (haq). Sebagai mana sabda Rosulallah Saw: "Tidak dihalalkan darah seorang muslim yang bersaksi bahwasanya tidak ada Ilah (yang haq) selain Allah dan Muhammad adalah Rasul Allah kecuali dengan tiga alasan, yaitu: jiwa dengan jiwa, seorang laki-laki beristeri yang berbuat zina, dan orang yang meninggalkan agamanya dan memisahkan diri dari jama'ah." (HR. Al-Bukhari dan Muslim). ${ }^{39}$

Salah satu tujuan syariat yang paling fundamental adalah menjaga jiwa manusia. Dasar ini bisa diterapkan apabila pemulangan WNI eks ISIS ke Indonesia

37 Abdul Basith Junaidy. "Menimbang Maslahah Sebagai Dasar Penetapan Hukum (Kajian terhadap Pemikiran Muhammad Abu Zahrah)." Al-Qanun: Jurnal Pemikiran dan Pembaharuan Hukum Islam 18.2 (2015), h.342

38 Departemen Agama RI, al-Quran dan Trjmahnya. (Jakarta: Gema Risalah Press, 1993), h.544

${ }^{39}$ https://alquranmulia.wordpress.com/2015/09/13/tafsir-ibnu-katsir-surah-an-israa-ayat-33/ diakses pada 09/03/2020. 
ternyata membahayakan orang lain maka hal tersebut wajib ditolak. Hal ini sesuai dengan kaidah fiqh;

$$
\text { الضرريزال }
$$

Artinya:

"Bahaya harus dihilangkan".

Sebagai agama yang menghendaki perdamaian, Islam selalu mengedepankan kemaslahatan dalam mengatur kehidupan manusia. Sehingga, banyak ayat dan hadits yang melarang untuk melakukan hal yang bisa menimbulkan kemadaratan dan bahaya bagi diri kita dan orang lain. Kaidah di atas adalah kaidah yang menjadi acuan umat Islam untuk menjauhi perkara yang membahayakan. Kaidah tersebut merupakan intisari dari hadits Nabi Saw:

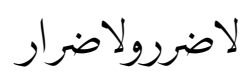

Artinya:

“Tidak boleh melakukan perbuatan yang membahayakan diri sendiri dan membahayakan orang lain".

Konsep Maqāṣid yang digagas oleh Jasser Auda utamanya tentang hak asasi manusia memiliki relevansi dengan Pasal 28J UUD 1945 "(1) Setiap orang wajib menghormati hak asasi manusia orang lain dalam tertib kehidupan bermasyarakat, berbangsa, dan bernegara. (2) Dalam menjalankan hak dan kebebasannya, setiap orang wajib tunduk kepada pembatasan yang ditetapkan dengan undang-undang dengan maksud semata-mata untuk menjamin pengakuan serta penghormatan atas hak dan kebebasan orang lain dan untuk memenuhi tuntutan yang adil sesuai dengan pertimbangan moral, nilai-nilai agama, keamanan, dan ketertiban umum dalam suatu masyarakat demokratis." ${ }^{41}$

Menurut ketentuan pasal tersebut, hak asasi manusia tidak bersifat subjektif saja, namun juga harus berdampak pada hak orang lain. Maksudnya, dalam memenuhi hak seseorang, ada hak orang lain yang tidak boleh dilanggar. Ketentuan pemenuhan hak asasi manusia di Indonesia juga dibatasi dengan nilai-nilai moral, agama, kesusulilaan dan harus menjaga ketertiban di masyarakat.

Menurut Abu Zahrah, pemberlakuan syariat bagi umat Islam adalah upaya untuk menciptakan kemaslahatan. ${ }^{42}$ Untuk itu, ciri khas hukum yang bisa dikategorikan mengandung kemaslahatan setidaknya memilik tiga ciri: Usaha untuk membersihkan diri setiap individu agar menjadi sumber kebajikan bagi masyarakatnya serta tidak menjadi sumber kejahatan bagi mereka. Hal itu

${ }^{40}$ M. Hamim HR dan Ahmad Muntaha AM, Pengantar Kaidah Figh Syafi'iyah, (Kediri: Lirboyo Press, 2013), h.7

${ }^{41}$ Ketentuan Pasal 28J ayat 1 dan 2 UUD 1945

42 Abdul Basith Junaidy,. "Menimbang Maslahah Sebagai, h.339 
diupayakan melalui pelaksanaan ritual-ritual keagamaan seperti ibadah mahdah dan ghairu mahdah. Syariat harus mencerminkan kemaslahatan dalam semua aspek kehidupan masyarakat. Hal ini, hukum yang menimbulkan kerusakan patut untuk ditolak pemberlakuannya. Bahkan, kemaslahatan yang tidak sesuai dengan nash juga tidak dibenarkan untuk dijalankan.

Menyikapi pro-kontra pemulangan WNI eks ISIS, untuk mencapai mașlahạ yang hakiki maka terlebih dahulu dipertimbangkan maqoshid al-syari'ah yang paling fundamental yaitu menjaga agama (hifz al-dīn), jiwa (hifz al-nafs), harta (hifz al-māl), akal (hifžu al-'aql) dan keturunan (hifẓu al-nasl). ${ }^{43}$ Penolakan oleh pemerintah bisa dibenarkan jika seluruh WNI eks ISIS adalah pelaku terorisme, namun yang menjadi masalah adalah istri dan anak-anak mereka yang menjadi korban kesalahan ideologi kepala keluarganya. Menurut penulis, sebagaimana dikutip dari pendapat Jasser Auda salah satu poin Maqāṣid al-syariah yang dapat dijadikan dasar penegakan hak asasi manusia adalah hif̧̣u al-dīn (menjaga hidup) dan hifẓu al-nasl (menjaga keturunan) sebagai bentuk kepedulian pemerintah terhadap anak-anak dan istri-istri simpatisan ISIS tersebut. $^{44}$

\section{b). Upaya Deradikalisasi di Indonesia}

Pembuat kerusakan terutama orang-orang dengan ideologi yang keras dalam syariat memang harus diusir dari suatu negara. Namun, dalam konteks ini, deradikalisasi adalah upaya untuk memenuhi hak istri dan anak-anak mereka. Maqāṣid al-syariah sebagai pertimbangan hukum juga memandang penting untuk melindungi dan memenuhi hak korban simpatisan ISIS tersebut.

1). Hifžu al-aql sebagai solusi bagi istri dan anak simpatisan ISIS

Menjaga keturunan tidak hanya melalui apek perkawinan saja, namun juga upaya untuk menjaga pemikiran anak agar tidak meleceng dari ajaran Islam yang sebenarnya. Simpatisan ISIS berbeda dengan simpatisan organisasi teroris pada umumnya. Untuk menjadi simpatisan, kepala keluarga juga mengajak anak dan istirnya melakukan jihad sebagai perintah suci agama. Sehingga mereka perlu diselamatkan dari doktrin-doktirin dan tipu daya konspirasi yang merusak masa depan mereka. ${ }^{45}$

Anggapan mereka sebagai pelaku terorisme tidaklah tepat. Hal ini karena mereka hanya korban dari ajakan orang tuanya yang sudah lebih dulu menganut

\footnotetext{
${ }^{43}$ Wahbah Zuhaili, Al-Tafsir al-Munir li al-Zuhail Jilid 7 (Damaskus: Dar al-Fikri al-Mu'ashir, 1418), h.322

44 Siti Mutholingah dan Muh. Rodhi Zamzami, h.108

${ }^{45}$ Mush'ab Muqoddas Eka Purnomo. "Kritik Narasi Populisme Islam di Mesir Pasca Arab Spring". Ma'arif, 14.1 (2019), h.131
} 
paham radikal. Menyikapi hal ini, seharusnya ada solusi dari pemerintah dan upaya untuk menjaga anak bangsa kembali berideologi Pancasila. Anak simpatisan ISIS bisa dikategorikan sebagai anak terlantar, anak yatim (jika orang tuanya meninggal dalam upaya terorisme) dan anak-anak simpatisan ISIS masih memiliki hak yang wajib dipenuhi oleh negara. Hal ini sesuai dengan ketentuan UUD 1945 "fakir miskin dan anak-anak yang terlantar dipelihara oleh negara". ${ }^{46}$ anak-anak simpatisan ISIS juga termasuk anak terlantar, maka berdasarkan konstitusi, negara harus hadir untuk memenuhi hak-hak yang semestinya mereka dapatkan.

2). Hifžu al-aql sebagai upaya deradikalisasi melalui sistem pendidikan.

Yusuf Qhardawi menganggap ideologi radikal sebagai ideologi seseorang yang tidak muncul secara kebetulan, melainkan ada beberapa faktor yang mempengaruhi. Menurutnya, idologi radikal adalah pola pikir seseorang yang berubah dari ideologi asal karena lemahnya pengetahuan tentang hakikat agama dan sejarah mengenai teks Al-quran. ${ }^{47}$ Upaya deradikalisasi yang paling mungkin untuk dilaksanakan dan efektif adalah pendidikan pesantren. Sebagai lembaga yang berafilisasi dari organisasi terbesar di Indonesia (Nahdlatul Ulama), pesantren menawarkan kemaslahatan 'ammah yaitu kemaslahatan yang orientasinya adalah kesjahteraan umum di masyarakat. ${ }^{48}$

Pendidikan yang ditawarkan pesantren memiliki tujuan yang sama dengan Islam, yaitu pendidikan yang benar-benar menggambarkan Islam secara sempurna dan memabawa nilai-nilai kasih sayang bagi seluruh alam. ${ }^{49}$ Tentunya ini menjadi kontra argumen yang jelas bahwa Islam yang hakiki benar-benar bertolak belakang dengan idologi radikal. Hal ini sebagaimana firman Allah Swt. dalam Qs. alanbiya'/21:107.

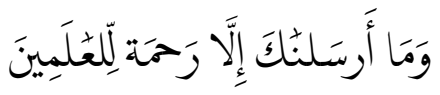

Artinya:

“Dan tiadalah Kami mengutus kamu, melainkan untuk (menjadi) rahmat bagi semesta alam." 50

Pendidikan pesantren di Indonesia dikenal dengan keefektifannya dalam mendidik karakter bangsa. Pendidikan karakter akan memiliki dampak pada perilaku, kebiasaan, motivasi dan keterampilan seseorang. Secara perlahan, melalui

${ }^{46}$ Ketentuan pasal 34 UUD 1945

47 Yusuf Qhardawi, Islam Radikal, (Solo: PT Era Adicitra Intermedia, 2013), h.88.

48 Yusuf Qhardawi, Islam Radikal, h. 89.

49 Ahmad Mukhtakif Billah. "Formulasi Konsep Maslahah 'Ammah Menurut Perspektif Nahdlatul Ulama Dalam Konteks Kehidupan Berbangsa Dan Bernegara”. Jurnal Wasathiyah, 2.1(2018), h.108

${ }^{50}$ Departemen Agama RI, Al Qur'an dan Terjemahannya, (Semarang: Asy Syifa', 1992), h.508. 
pendidikan karakter di pesantren, pemikiran ekstimisme seseorang akan dididik dengan pengetahuan, kesadaran dan tekad sehingga akan membentuk pribadi yang memiliki tekad dan kemauan untuk melaksanakan nilai-nilai baik pada orang lain. Tentunya hal ini akan menjadi solusi bagi pemerintah, jika berkenan untuk memberi kesemepatan WNI eks ISIS pulang kembali ke Indonesia.

\section{KESIMPULAN}

Probelamatika utama yang dihadapi pemerintah adalah kebijakan yang akan diterapakan untuk menylesaikan masalah tentang WNI eks ISIS yang ada di Iraq dan Suriah. Penulis mencoba untuk menganalisis kasus tersebut berdasarkan konsep mașlahah untuk mencari solusi terbaik. Maka, dari semua pembahasan di atas dapat penulis tarik menjadi beberapa poin kesimpulan sebagai berikut:

Dari 678 orang warga negara Indonesia yang menjadi simpatisan ISIS di Iraq dan Suriah tidak semuanya bisa disebut sebagai pelaku terorisme. pasalnya, tidak semua dari mereka adalah orang dewasa yang dengan suka rela menjadi simpatisan. Menurut media, ada dari mereka yang masih berusia 12-21 (kategori anak-anak) dan perempuan-perempuan istri simpatisan ISIS yang juga terpaksa ikut kepala keluarganya.

Pemberontak atau perusak dalam hukum Islam, memang tidak diperkenankan untuk kembali ke suatu negara atau harus diusir dari negaranya. Namun, istri dan anak-anak bukanlah pelaku, karena itu seharusnya mereka tetap mendapat hak-hak mereka sebagai warga negara Indonesia.

Menurut konsep Maqāṣid Jasser Auda dan Pasal 28 J UUD 1945, hak asasi manusia tidak bisa didefinisikan sebabagi pemenuhan hak secara personal. Perlu juga memperhatikan agar tidak melanggar hak orang lain. Di Indonesia hak asasi manusia dibatasi dengan nilai-nilai agama, norma kesusilaan, ketertiban dan keamanan masyarakat. Sejalan dengan itu, Abu Zahra berpendapat bahwa maṣlahah sebagai tujaun Maqāṣid al-Syarīah harus mementingkan kemaslahatan umum atau universal. Oleh sebab itu, penolakan pemerintah untuk memulangkan pelaku terorisme adalah kebijakan yang benar dan sesuai dengan syariat.

Untuk memenuhi hak istri dan anak-anak simpatisan ISIS, maka solusi terbaik adalah melalui deradikalisasi sebelum kembali hidup bersama masyarakat. Dalam maqāṣid deradikalisasi berfungsi untuk menjaga akal (hifẓu al-aql) dan menjaga keturunan (hifžu al-nasl). 


\section{DAFTAR PUSTAKA}

Ariyanto, Yus, 5 jejak ISIS di Indonesia, https://www.liputan6.com/news/read diakses pada 21 April 2020.

Ashiddiqie, Jimly, 2016, Pengantar Hukum Tatanegara II, Sekretaris jenderal Kepaniteraan Mahkamah Konstitusi RI, Jakarta.

Bawole, Merryany, "Kajian Hak Asasi Manusia terhadap Perlakuan Diskriminasi Kepada Pekerja Seks Komersial", Jurnal Hukum UNSRAT, Vol. 21, No.3, Juni 2013.

Billah, Ahmad Mukhtakif, "Formulasi Konsep Maslahah 'Ammah Menurut Perspektif Nahdlatul Ulama Dalam Konteks Kehidupan Berbangsa Dan Bernegara", Jurnal Wasathiyah, Vol. 2, No. 1, Pebruari 2018.

Departemen Agama RI, 1992, Al Qur'an dan Terjemahannya, Asy Syifa', Semarang.

Fatkhi, Rifqi Muhammad and Reva Hudan Lisalam, "Membumikan HAM Mengikis Perbudakan (Kajian Mawḍ̂u'î Terhadap Ḥadîts-ḥadîts Perbudakan)," Refleksi, Vol. 17, No .2, Juni 2018.

Haitami, Enden, 2015, “Perkembangan Teori Mashlahah 'Izzu Al-Dîn bin 'Abd AlSalâm dalam Sejarah Pemikiran Hukum Islam", Asy Syari'ah, Vol. 17, No.1., Januari 2015.

Hidayat, Eko, "Perlindungan hak asasi manusia dalam negara hukum indonesia", ASAS, Vol. 8, No. 2, Juli 2018.

HR, M. Hamim dan Ahmad Muntaha AM, 2013, Pengantar Kaidah Fiqh Syafi'iyah, Lirboyo Press, Kediri.

https://alquranmulia.wordpress.com/2015/09/13/tafsir-ibnu-katsir-surah-an-israa-ayat-33/ diakses pada 09/03/2020.

Junaidy, Abdul Basith, "Menimbang Maslahah Sebagai Dasar Penetapan Hukum (Kajian terhadap Pemikiran Muhammad Abu Zahrah)," Al-Qanun: Jurnal Pemikiran dan Pembaharuan Hukum Islam, Vol. 18, No.2, Agustus 2015.

Kholis, Nur, "Pondok pesantren salaf sebagai model pendidikan deradikalisasi terorisme." Akademika: Jurnal Pemikiran Islam, Vol. 22, No. 1, Januari 2017.

Marwan, M dan Jimmy.P, 2009, Kamus Hukum, Pustaka Pelajar, Yogyakarta.

Masduqi, Irwan Masduqi, "Deradikalisasi Pendidikan Islam Berbasis Khazanah Pesantren", Jurnal Pendidikan Islam, Vol. 2, No. 1, April 2013.

Matompo, Osgar S, "Pembatasan Terhadap Hak Asasi Manusia Dalam Prespektif Keadaan Darurat", Media Hukum, Vol. 21, No. 1, Mei 2014.

Muhtaj, Majda El, 2015, Hukum dan Hak Asasi Manusia dalam Konstitusi Indonesia, Kencana. Jakarta.

Muqoyyidin, Andik Wahyun, "Membangun kesadaran inklusifmultikultural untuk deradikalisasi pendidikan Islam", Jurnal Pendidikan Islam, Vol. 2, No.1, Mei 2013. 
Mutholingah, Siti dan Muh. Rodhi Zamzami, " Relevansi Pemikiran Maqashid AlSyari'ah Jasser Auda Terhadap sistem Pendidikan Islam Multidisipliner, Ta'limuna, Vol. 7, Vol. 2, Juni 2018.

Chatrine, Rahel Narda, Soal WNI eks ISIS, Komnas HAM sarankan Pemerintah Lakukan Profilling, https://news.detik.com/berita/d-4892152/soal-wni-eks-isis-komnas-ham, dikses pada 14 April 2020.

Pratsetia, Andika, Tok! Pemerintah Tak Akan Pulangkan WNI eks ISIS, news.detik.com/berita/d-4894943/tok-pemerintah-tak-akan-pulangkan-wnieks-isis diakses pada 11 April 2020.

Purnomo, Mush'ab Muqoddas Eka Purnomo, “Kritik Narasi Populisme Islam di Mesir Pasca Arab Spring", Ma'arif, Vol. 14, No. 1, April 2019.

Pusat Pengkajian dan Pengembangan Ekonomi Islam, 2015, Ekonomi Islam, Radja Grafindo Persada, Jakarta.

Qardhawi, Yusuf, 2003, Pemikiran Yusuf Qhardawi dalam Timbangan, terj. M. Abdul Ghoffar, Pustaka Imam Syafi'i, Bogor.

Qardhawi, Yusuf, 2013, Masyarakat Berbasis IslamI, terj. Abdus Salam Masykur, PT Era Adicitra Intermedia, Solo.

Qhardawi, Yusuf, 2013, Islam Radikal, PT Era Adicitra Intermedia, Solo.

Rakhmad, Abu, "Radikalisme Islam dan Upaya Deradikalisasi Paham Radikal". Jurnal Walisongo, Vol. 1, No. 12, Januari 2012.

Sabla, Amira Rahma, 2017, "Kajian Freedom of Speech and Expression dalam Perlindungan Hukum terhadap Demonstran di Indonesia." Lex Scientia Law Review, Vol. 1, No. 01,Oktober 2017.

Tumundo, Edwin, "Penyidikan Tindak Pidana Perdagangan Orang pada Tingkat Kepolisian dalam Perspektif Hak Asasi Manusia", Lex Et Societatis, Vol. 6, No. 4, Juli 2018.

Wirawan, Wahyu, "Peran Militer Dalam Gerakan Massa Dan Pembunuhan Massal Di Jawa-Bali", Jurnal Historia, Vol. 23, No. 2, April 2013.

Zakariya, Ahmad bin Faris, 1979, Mu'jam Maqoyiz al-Lughah, Dar al-Fikr, Beirut

Zuhaili, Wahbah, 1418, Al-Tafsir al-Munir li al-Zuhail Jilid 7, Dar al-Fikr, Damaskus. 